UDC 004.4:621.396.933 (045)

DOI: $10.18372 / 1990-5548.56 .12940$

\author{
${ }^{1}$ M. P.Mukhina, \\ ${ }^{2}$ O. Yu. Tkachenko, \\ ${ }^{3}$ I.V.Barkulova
}

\title{
ACCURACY RESEARCH METHOD OF THE MODIFIED ALGORITHM FOR DETECTING LINEAR LANDMARKS
}

\author{
${ }^{1,2,3}$ Educational \& Research Institute of Information and Diagnostic Systems, \\ National Aviation University, Kyiv, Ukraine \\ E-mails: ${ }^{1}$ marinamukhina79@gmail.com, ${ }^{2}$ OlenaTkachenko@bigmir.net, ${ }^{3}$ irochkaseden@gmail.com
}

\begin{abstract}
A search algorithm for the most extended landmark by which unmanned aerial vehicle can be followed by and implemented flight correction was proposed. The software was developed based on the Python language. The functionality of this software is to detect the linear landmarks from images of geophysical field, received from unmanned aerial vehicle in real time. Images were processed by Hough Line Transform method. As a result, obtained visualization of the object detection with the greatest length, as linear landmark, which allows to estimate unmanned aerial vehicle location. The visual analysis of the effectiveness of this algorithm for inertial navigation system correction shown that the algorithmic software is appropriate for use on unmanned aerial vehicle board and due to applying computer vision systems, gives as correct results of location determining as possible.
\end{abstract}

Index Terms - Houghline transform method; Canny detector; linear landmarks; aided navigation.

\section{INTRODUCTION}

Unmanned aerial vehicles (UAV) have gained increased interest in computer vision research. To navigate safely, this flying machine needs the ability to localize itself autonomously using its onboard sensors. One of such sensor is a camera. Its purpose is ability to estimate motion from images (including interest point detection, feature descriptors, error estimation, and iteratively closest point). It is very useful to develop such autonomous control system, to have auto piloted aircrafts orientate in space much faster, react efficiently, by getting an information from various amount of data sources like GPS, inner sensors and data from ground center [1]. However, for developing an efficient data exchange, previous researches of efficiency needed.

It is very useful to develop such autonomous control system, to have auto piloted aircrafts orientate in space much faster, react efficiently, by getting an information from various amount of data sources like GPS, inner sensors and data from ground center.

Using the transmitter of electronic jamming for GPS system, it is possible to disrupt the receiver of this navigation system. As a result, the receiver loses the ability to determinate the coordinates of the objects and navigation of UAV becomes unreliable. Accuracy of only one inertial navigation system (INS), based on gyros, for determination of UAV coordinates location is not enough, its degrades with time significantly. Therefore, it requires alternative variant for data integration and INS errors compensation. In such situation, the possible solution may be the visual navigation [2].

\section{Problem Statement}

One of the fundamental moments of visual navigation is to take information about the position and motion parameters of the object relatively the environment. To determine the aircraft coordinates position fix method is used. The method is based on using the surfaces of lines of position (LOP) to determine the object location.

Position surface is the geometric locus of points where possibly the object is located relatively the Earth, and where the physical parameter is constant to be measured onboard or at ground [3].

The mathematical description of position surface has the following form:

$$
F=f(x, y, z),
$$

where $x, y, z$ are coordinates of aircraft location.

Properties of position surface are defined by the following characteristics: geometric shape $f(x, y, z)$; gradient $q$; offset error $\sigma_{\text {offset }}$. The geometric shape is found as a result of building the function $f(x, y, z)=$ const in the assumed coordinate system. The gradient characterizes the rate and direction of highest change in function $f(x, y, z)$. The gradient direction is always normal to the position surface. The expression of gradient has the form:

$$
q=\lim _{\Delta n \rightarrow 0} \frac{\Delta f}{\Delta n}
$$

where $\Delta f$ is the function increment; $\Delta n$ is the value of translational motion of position surface. 
Root-mean-square error of position surface offset relatively the true aircraft location is determined as

$$
\sigma_{\text {offset }}=\frac{\sigma_{f}}{q}
$$

where $\sigma_{f}$ is the root-mean-square error of measurement of parameter $f$, that defines the position surface.

To solve the navigation tasks, that is to determine the spatial aircraft location (the coordinates $x, y, z$ ) it is necessary to have three different position surfaces $F_{i}=f_{i}(x, y, z),(i=1,2,3)$ which are intersected. The intersection of two position surfaces with ground surface determines the object location of the Earth surface.

Line-of-position (LOP) is a geometric locus of points of projection of possible aircraft location on the Earth surface with constant navigation parameter. That is, LOP is created as a result of intersection between position surface and ground surface. Properties of LOPs, the same as position surfaces, are defined by geometric shape, gradient and offset error.

Use of LOPs in navigation is of long standing. Navigator determined a navigation parameter, e.g., bearing of navigation point(NP), and then on map built a line corresponding to the measured parameter. Then again the navigator did the same: measured another navigation parameter and built the second LOP [4]. By the point of two lines intersection he defined the location.

In aeronavigation the following LOPS can be used:

- curve of equal bearings,

- circle of position,

- hyperbola,

- astronomic LOP.

To LOPs it is also possible to relate a rhumb line, that is a line which crosses the geographical meridians at the same angle; and a great circle, that is an arc of great circle which is the shortest distance between any two points on the Earth surface.

In radio navigation systems the following LOPS are used frequently (Fig. 1):

- curves of equal bearings $(\nexists=A=$ const $)$ are straight lines which pass through NP;

- circles of position $(\nexists=D=$ const $)$ are circles with center in NP;

- hyperboles which are curves with equal difference in distance towards two navigation points $\mathrm{NP}_{1}$ and $\mathrm{NP}_{2}\left(\bigoplus=\Delta D=D_{1}-D_{2}=\right.$ const $)$.

Position fix method is the base for construction of systems operating by visual landmarks. Such land- marks can be linear objects like road, coast-line, horizonline.
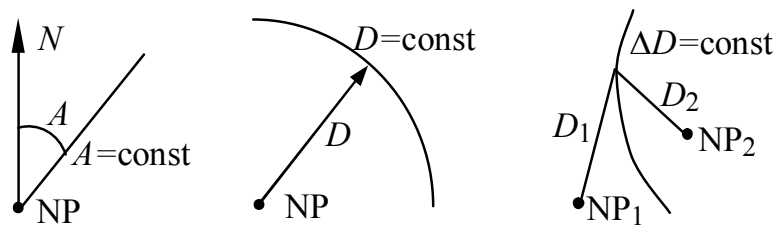

Fig. 1. LOPS in radio navigation systems

\section{AlgORITHM AND ANALYSIS OF METHOD FOR DETECTING LINEAR REFERENCE POINTS}

The Hough Line Transform is a transform used to detect straight lines. In OpenCV it is implemented with the function HoughLines. To apply the Transform, first an edge detection pre-processing is desirable.

A line in the image space can be expressed with two variables. Forexample:

a. In the Cartesian coordinate system: Parameters: $(m, b)$.

b. In the Polar coordinate system: Parameters: $r, \theta$ (Fig. 2).

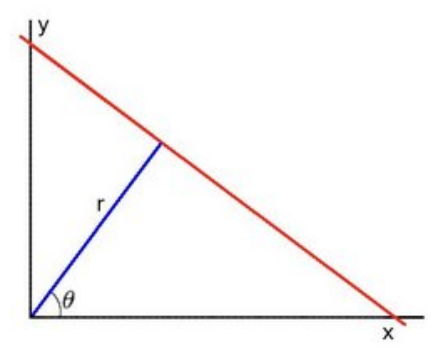

Fig. 2. The Polar coordinate system

For Hough Transforms, lines in the Polar system will be expressed. Hence, a line equation can be written as:

$$
y=\left(-\frac{\cos \theta}{\sin \theta}\right) x+\left(\frac{r}{\sin \theta}\right)
$$

Arranging the terms: $r=x \cos \theta+y \sin \theta$.

In general for each point $\left(x_{0}, y_{0}\right)$, the family of lines that goes through that point can be defined as:

$$
r_{0}=x_{0} \cos \theta+y_{0} \sin \theta .
$$

Meaning that each pair $\left(r_{0}, \theta\right)$ represents each line that passes by $\left(x_{0}, y_{0}\right)$.

If for a given $\left(x_{0}, y_{0}\right)$, we plot the family of lines that goes through it, we get a sinusoid.

Let consider only points such that $r>0$ and $0<\theta<2 \pi$.

The same operation can be done above for all the points in an image. If the curves of two different 
points intersect in the plane $\theta-r$, that means that both points belong to a same line.

The three plots intersect in one single $A$ line can be detected by finding the number of intersections between curves. The more curves intersecting means that the line represented by that intersection have more points. In general, we can define a threshold of the minimum number of intersections needed to detect a line.

This is what the Hough Line Transform does. It keeps track of the intersection between curves of every point in the image. If the number of intersections is above some threshold, then it declares it as a line with the parameters $\left(\theta, r_{\theta}\right)$ of the intersection point.

It can be observed that the number of lines detected vary while you change the threshold. The explanation is sort of evident: If you establish a higher threshold, fewer lines will be detected (since you will need more points to declare a line detected).

\section{EXPERIMENTAL RESULTS}

Images processing by Houghline transform. With the help of Hough line transform we can identify lines in both images and videos.

Capture Video from Camera in real time mood. Obviously, we have to capture live stream with camera on the board of the UAV. For the experiment was used the in-built webcam of the laptop to capture a video from the camera. It was decided to use a chessboard for this experiment. Since chessboards in particular - are often used to demonstrate feature extraction algorithms because their regular geometry naturally exhibits local image features like edges, lines, and corners. The grid structure of a chessboard naturally defines two sets of parallel lines in an image of it. Therefore, one expects that line detection algorithms should successfully detect these lines in practice. Indeed, the Fig. 3 demonstrates Hough transform-based line detection applied to a perspective-transformed chessboard image.

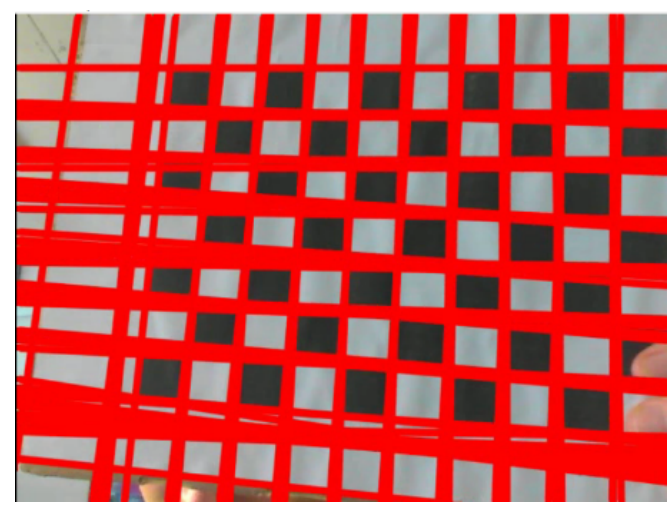

Fig. 3. Line detection on the video in real time mood
It can be observed, that Hough transform is able to accurately detect the lines induced by the board squares.

There is the strobing of light from the window on the Fig. 4, do some additional features should be applied to avoid wrong lines detection.

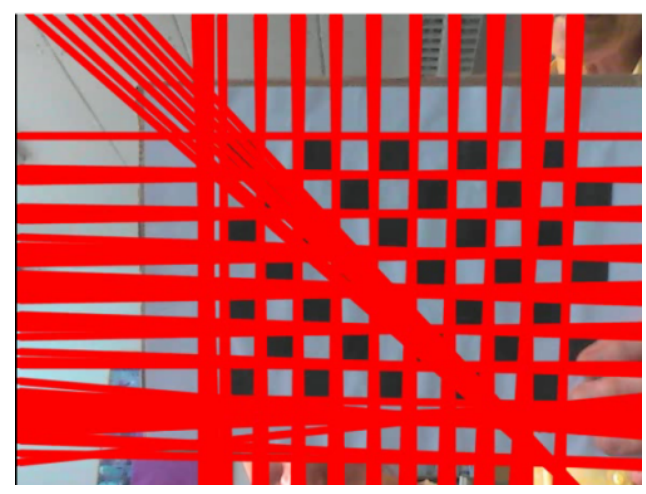

Fig. 4. Strobing of light from the window

The study of proposed algorithms has been done on the series of images of camera from UAV.

The threshold value can be correlated during work with images to obtain the best result of landmark detecting (Fig. 5). The correspondences between the threshold value and the quantity of detected lines are collected in the Table I.

TABle I. Changes of Threshold PARAMETER

\begin{tabular}{|c|c|c|c|}
\hline Frame & Threshold & $\begin{array}{c}\text { Quantity of } \\
\text { detected lines }\end{array}$ & $\begin{array}{c}\text { Quantity of } \\
\text { unique lines }\end{array}$ \\
\hline 1 & 300 & 1 & 1 \\
\hline 1 & 250 & 5 & 2 \\
\hline 1 & 200 & 16 & 3 \\
\hline 2 & 200 & 8 & 3 \\
\hline 2 & 230 & 6 & 2 \\
\hline 2 & 250 & 4 & 1 \\
\hline
\end{tabular}

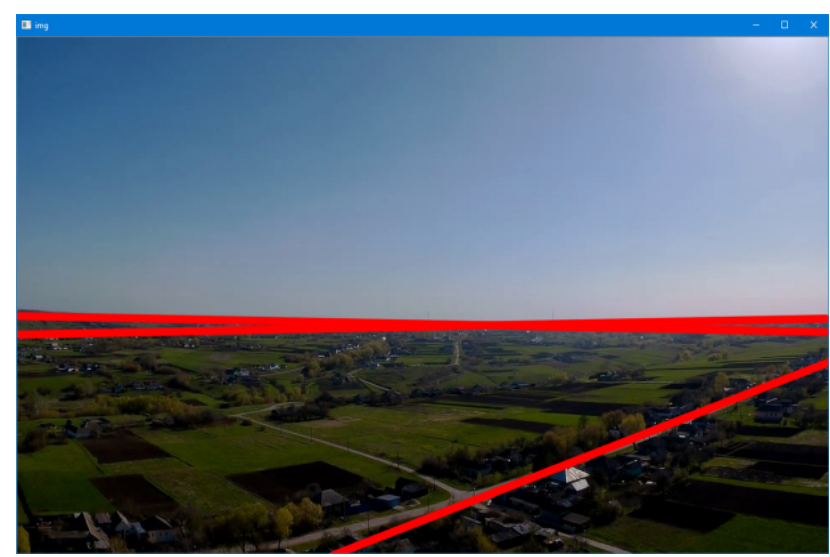

Fig. 5. Received determination of the main road (horizon line is detected as landmark)

Video processing from the video file. Roads detected by Hough line transform on the experimented video previously received from the UAV (Fig. 6). 


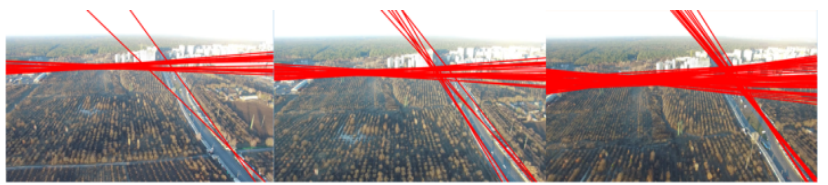

Fig.6. Detection of the roads as landmarks from the video

\section{CONCLUSIONS}

To evaluate the efficiency of the proposed algorithm the observation method was chosen. The operator estimation results of the line detecting are as following.

The results showed that the use of this technique, the orientation evaluation UAV allows us to solve a number of high-precision tasks such as accurate positioning and following along a landmark, the problem of targeting, automatic landing and others.

During the experiments, were tested 56 frames, 42 of which was contains a detected landmark. Some over lighted frames were not recognized by the algorithm, but in the test condition with laptop camera the efficiency of the algorithm increased up to $100 \%$. This means that the additional filters are required for solar condition same as rigid fixation of the UAV camera perpendicularly to the ground surface.

So, during the performance of work proposed an approach to solving the problem of determining the landmarks with $87.5 \%$ of efficiency for orientation of the UAV.

\section{REFERENCES}

[1] Kusainov A. A. Development of control system unmanned aerial vehicle along a predetermined path. Novosibirsk, 2013. - 60 p.

[2] Hartley R., Zisserman A. Multiple view geometry in computer vision. - Australian National University, Canberra, Australia. - Cambridge University Press 2000, 2003. - 673 p.

[3] В.О. Рогожин, В.М. Синєглазов, М.К. Філяшкін. Пілотажно-навігаційнйкомплексиповітрянихсуде н: Підручник - К.: НАУ, 2005.

[4] Javed, and M. Shah, "Tracking and object classification for automated surveillance," in European Conference on Computer Vision, Springer, Berlin, Heidelberg, 2002, pp. 343-357.

Received March 07, 2018.

MarynaMukhina. Doctor of Engineering Science. Professor.

Aviation Computer-Integrated Complexes Department, Educational \& Research Institute of Information and Diagnostic Systems, National Aviation University, Kyiv, Ukraine.

Education: National Aviation University, Kyiv, Ukraine, (2002).

Research area: Navigation and motion control.

Publications: more than 60 papers.

E-mail: marinamukhina79@gmail.com

OlenaTkachenko. Master's.

Aviation Computer-Integrated Complexes Department, Educational \& Research Institute of Information and Diagnostic Systems, National Aviation University, Kyiv, Ukraine.

Education: National Aviation University, Kyiv, Ukraine, (2018).

Research area: Navigation and motion control.

Publications: more than 8 papers.

E-mail: OlenaTkachenko@bigmir.net

IrynaBarkulova. Post-graduate student.

Aviation Computer-Integrated Complexes Department, Educational \& Research Institute of Information and Diagnostic Systems, National Aviation University, Kyiv, Ukraine.

Education: National Aviation University, Kyiv, Ukraine, (2014).

Research area: Navigation and motion control.

Publications: more than 12 papers.

E-mail: irochkaseden@gmail.com

М. П. Мухіна,О. Ю. Ткаченко, І. В. Баркулова. Методика дослідження точності модифікованого алгоритму виявлення лінійних оріснтирів

Розроблено алгоритм пошуку найбільш протяжного орієнтира, за яким БПЛА може слідувати і здійснювати корекцію польоту. Алгоритмічне забезпечення було розроблено на основі мови Руthon. Функціональністю програмного забезпечення є виявлення лінійних орієнтирів на зображеннях геофізичного поля, отриманих з борту БПЛА у режимі реального часу. Дані зображення оброблено методом перетворення Хафа. У результаті отримано візуалізацію виявлення об'єкта 3 найбільшою протяжністю, тобто лінійного орієнтира, що дозволяє оцінювати місцезнаходження БПЛА. Проведений візуальний аналіз ефективності алгоритму для корекції ІНС показав, що дане алгоритмічне забезпечення є вдалим варіантом для використання на борту БПЛА, а завдяки застосуванню систем технічного зору, дає найбільш точний результат у визначенні місця розташування БПЛА. 
Ключові слова: перетворення Хафа; детектор границь Кенні; лінійні орієнтири; навігаційна система 3 корекцією.

Мухіна Марина Петрівна. Доктор технічних наук. Професор.

Кафедра авіаційних комп’ютерно-інтегрованих комплексів, Навчально-науковий інститут інформаційно-діагностичних систем,Національний авіаційний університет, Київ, Україна.

Освіта: Національний авіаційний університет, Київ, Україна, (2002).

Напрям наукової діяльності: навігація та управління рухом.

Кількість публікацій: понад 60.

E-mail: marinamukhina79@gmail.com

Ткаченко Олена Юріївна. Магістр.

Кафедра авіаційних комп’ютерно-інтегрованих комплексів, Навчально-науковий інститут інформаційно-діагностичних систем,Національний авіаційний університет, Київ, Україна.

Освіта: Національний авіаційний університет, Київ, Україна, (2018).

Напрям наукової діяльності: навігація та управління рухом.

Кількість публікацій: понад 8.

E-mail: OlenaTkachenko@bigmir.net

БаркуловаІрина Володимирівна. Аспірант.

Кафедра авіаційних комп'ютерно-інтегрованих комплексів, Навчально-науковий інститут інформаційних діагностичних систем,Національний авіаційний університет, Київ, Україна.

Освіта: Національний Авіаційний Університет, Київ, Україна, (2014).

Напрям наукової діяльності: навігація та управління рухом.

Кількість публікацій: понад 12.

E-mail: irochkaseden@gmail.com

М. П. Мухина, О. Ю. Ткаченко, И. В. Баркулова. Методика исследования точности модифицированного алгоритма выявления линейных ориентиров

Разработано алгоритм поиска наиболее протяженного ориентира, по которому БПЛА может следовать и совершать коррекцию полета. Алгоритмическое обеспечение было разработано на основе языка Руthon. Функциональность программного обеспечения состоит в определении линейных ориентиров на изображениях геофизического поля, полученных с борта БПЛА в режиме реального времени. Данные обработаны методом преобразования Хафа. В результате получено визуализацию определения объекта с наибольшей протяженностью, то есть, линейный ориентир, что позволяет оценивать местоположение БПЛА. Проведенный визуальный анализ эффективности алгоритма для коррекции ИНС показал, что представленное алгоритмическое обеспечение является удачным вариантом для использования на борту БПЛА, и благодаря использованию систем технического зрения, показывает наиболее точный результат в определении местоположения БПЛА.

Ключевые слова: преобразование Хафа; детектор границ Кенни; линейные ориентиры; навигационная система с коррекцией.

Мухина Марина Петровна. Доктор технических наук. Профессор.

Кафедра авиационных компьютерно-интегрированных комплексов, Учебно-научный институт информационно-диагностических систем, Национальный авиационный университет, Киев, Украина.

Образование: Национальный авиационный университет, Киев, Украина, (2002).

Направление навигация и управление движением.

Количество публикаций: более 60.

E-mail:marinamukhina79@gmail.com

ТкаченкоЕленаЮрьевна. Магистр.

Кафедра авиационных компьютерно-интегрированных комплексов, Учебно-научный институт информационно-диагностических систем, Национальный авиационный университет, Киев, Украина.

Образование: Национальный авиационный университет, Киев, Украина, (2018).

Направление навигация и управление движением.

Количество публикаций: более 8.

E-mail: OlenaTkachenko@bigmir.net

Баркулова Ирина Владимировна. Аспирант.

Кафедра авиационных компьютерно-интегрированных комплексов, Учебно-научный институт информационно-диагностических систем, Национальный авиационный университет, Киев, Украина.

Образование: Национальный авиационный университет, Киев, Украина, (2014).

Направление навигация и управление движением.

Количество публикаций: более 12.

E-mail: irochkaseden@gmail.com 